\section{ПРАВОВЕ РЕГУЛЮВАННЯ ПОСВІДЧЕННЯ ДОГОВОРУ АОВІЧНОГО УТРИМАННЯ (АОГлядУ) ${ }^{\circ}$}

O.A. ГАВІНСБКА, кандидат юридичних наук, асистент кафедри права, Вінницький національний аграрний університет (м. Вінниця)

У статті розглядається діючий в Украӥні порядок посвідчення договору довічного утримання (догляду). Автором аналізується його теоретична і правова основа, особливості виникнення проблем та наслідків з такого виду договору при реалізачії прав та інтересів потениійних контрагентів. Обтрунтована необхідність нотаріального посвідчення договору довічного утримання на основі тривалості діi договору й алеаторності (ризиковості). Обов'язки нотаріуса при посвідченні договору такі: роз'яснення сторонам змісту $i$ значення поданого ними проекту договору; перевірка відповідності змісту проекту договору намірам сторін; встановлення несуперечності проекту договору вимогам закону.

Нотаріальна консультаџія полягає в ознайомленні з правами та обов'язками сторін: відчужувача та набувача. Автор детально означив існуючі переваги та недоліки (проблематику функиіонування) иьього виду договору зобов'язального права та висвітлив особливості його дї̈ на основі судових рішень й практики. Виокремлені проблеми пов'язувались із передачею нерухомого майна у власність набувача, доброчесності контрагентів договору, комплексності врахування умов договору відчужувачем, елемента введення в дію договору третьої особи та особливостям розірвання договору в судовому порядку. Роз'яснено наслідки виконання, припинення, розірвання договору довічного утримання (догляду). Автором зазначено, щзо ией інститут ичивільного права потребує більи детальної законодавчої регламентачії. Визначено прогалини законодавства щзодо прав і обов'язків сторін.

Ключові слова: договір, договір довічного утримання, нотаріальне посвідчення, державна реєстрація, відчужувач, набувач, ризики, консультація.

Літ.: 19.

\title{
LEGAL REGULATION OF THE LICENSE AGREEMENT IDENTIFICATION (CARE)
}

\author{
HAVINSKA Olena, \\ Candidate of Legal Sciences, \\ Lecturer of the Department of Law, \\ Vinnytsia National Agrarian University
}

(Vinnytsia)

The article deals with the procedure for certification of a life-support maintenance (care) contract in the law of Ukraine. The author analyzes its theoretical and legal basis, especially the emergence of problems and consequences of such a contract in realization the rights and interests of potential counterparties. The necessity of a notarial certificate of

() О.А. ГАВІНСЬКА, 2019 


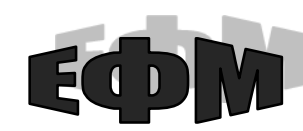

http://efm.vsau.org/

the contract of life maintenance on the basis of duration of the contract and its aleatore character is substantiated. The duties of the notary at the certification of the contract are as follows: clarification of the content of the contract and the value of the project submitted by them; verification of compliance of the content of the draft agreement with the intentions of the parties; establishment of a possible conflict between the draft contract and the requirements of the law.

The notarial consultation consists in familiarizing with the rights and obligations of the parties: the alienator and the acquirer. The author described in detail the existing advantages and disadvantages (the problems of functioning) of this type of contract of obligatory law and highlighted the peculiarities of its action on the basis of court decisions and practice. Some problems were associated with the transfer of the real estate property to the acquirer's property, the integrity of contracting parties to the contract, the complexity of taking into account the terms of the agreement by the alienator, the element of the commissioning of the third party agreement and the peculiarities of termination of the contract in the court. The consequences of the implementation and termination of the contract of life maintenance (care) are explained. The author states that this institute of civil law needs more detailed legal regulation. The gaps in legislation on the rights and obligations of the parties are noted.

Key words: contract, life-long maintenance agreement, notarization certificate, state registration, alienation, acquirer, risks, consultation.

Ref.:19.

\section{ПРАВОВОЕ РЕГУЛИРОВАНИЕ УДОСТОВЕРЕНИЯ ДОГОВОРА ПОЖИЗНЕННОГО СОДЕРЖАНИЯ (УХОДА)}

\section{ГАВИНСКАЯ Елена Андреевна, кандидат юридических наук, ассистент кафедры права, \\ Винницкий национальный аграрный университет}

(2. Винница)

В статье рассматривается действуюший в Украине порядок удостоверения договора пожизненного содержания (ухода). Автором анализируется его теоретическая и правовая основа, особенности возникновения проблем и последствий такого вида договора при реализачии прав и интересов потенщиальных контрагентов. Обоснована необходимость нотариального удостоверения договора пожизненного содержания на основе продолжстельности действия договора и алеаторности (рискованности). Обязанности нотариуса при удостоверении договора такие: разъяснение сторонам смысла и значения представленного ими проекта договора; проверка соответствия содержания проекта договора намерениям сторон; установление непротиворечивости проекта договора требованиям закона.

Нотариальная консультация заключается в ознакомлении с правами $u$ обязанностями сторон: отчуждателя и приобретателя. Автор подробно обозначил существующие преимущества и недостатки (проблематику функиионирования) этого вида договора обязательственного права и осветил особенности его действия на основе судебных решений и практики. Выделенные проблемы касаются передачи 
недвижсимого имущества в собственность приобретателя, добропорядосности контрагентов договора, комплексности учета условий договора отчуждателем, элемента введения в действие договора третьего лииа и особенностей расторжения договора в судебном порядке. Разъяснено последствия выполнения, прекращения, расторжения договора пожизненного содержания (ухода). Автором отмечено, что этот институт гражданского права требует более детальной законодательной регламентачии. Указань пробель законодательства относительно прав и обязанностей сторон.

Ключевые слова: договор, договор пожизненного содержания, нотариальное удостоверение, государственная регистрация, отчуждатель, приобретатель, риски, консультация.

Лит.: 19.

Постановка проблеми. Відносини власності з приводу передачі майна на основі укладення договору довічного утримання (догляду) наразі набули значного розвитку. Існуюче різноманіття договірних конструкцій передбачає можливість для кожного учасника цивільних відносин сформувати обов'язки і права сторін, обирати певні варіанти своєї поведінки в договорі, який вони укладають. Проте нездатність захистити свої права та необізнаність часто призводять до низки проблем. Договір довічного утримання (догляду) на практиці не містить єдиного розуміння зобов'язань та допускає зловживання правами учасниками такого договору. Вивчення практик нотаріального посвідчення договору довічного утримання (догляду) свідчить про те, що виникає значний обсяг питань, що потребують практичного обгрунтування на основі законодавчого вирішення.

Аналіз останніх досліджень і публікацій. Значний внесок у означену проблематику за договором довічного утримання (догляду) зроблено такими дослідниками: М.С. Долинською [4], І.П. Івашовою [6], О.В. Козир [7], М.В. Лаптошем, А.О. Куртаковою [9], О.В. Розгон [15], М.В. Ткаченко [17], Н.Л. Цопіною [19] та ін. Разом з тим, сучасний розвиток цивільно-правових відносин вимагає грунтовного аналізу правового регулювання 3 посвідчення договору довічного утримання (догляду).

Формулювання цілей статті. Метою статті $\epsilon$ дослідження правового регулювання посвідчення договору довічного утримання (догляду), а також внесення пропозицій щодо удосконалення законодавчого регулювання в цьому напрямі.

Виклад основного матеріалу дослідження. Договір довічного утримання (догляду) регулюється гл. 57 Цивільного кодексу України (далі - ЦК України) [18], спеціальними нормами Сімейного кодексу України [16], а також Законом України «Про нотаріат» [14], Порядком вчинення нотаріальних дій нотаріусами України [13]. Договір довічного утримання $є$ «правочином, згідно якого одна сторона (відчужувач) передає другій стороні (набувачеві) у власність житловий будинок, квартиру або їх частину, інше нерухоме майно або рухоме майно, яке має значну цінність, взамін чого набувач зобов'язується забезпечувати відчужувача утриманням та (або) доглядом довічно» (ст. 744 ЦК України) [18]. Відповідно до ст. 746 ЦК України сторонами договору довічного утримання $є$ набувач та відчужувач.

Для укладення будь-якого цивільно-правового договору необхідно визначити усі істотні умови договору та надання йому встановленої законом форми. Особливу увагу варто звернути на істотні умови, які названі в ст. 180 ГК України, про предмет, 
у значення якого в цьому випадку входить як нерухоме майно, що передається, так i його умова про вартість з утриманням (на місяць). Крім перерахованого вище, зміст договору встановлюється за домовленістю сторін. Однак сторони не завжди знають про значення або навіть про можливість знаходження в договорі тієї чи іншої умови.

Саме тому, і через соціальну значущість, і через знаходженні в ньому свідомо слабкої сторони в особі одержувача ренти, договір довічного утримання (догляду) підлягає нотаріальному посвідченню і державній реєстрації (ст. 745 ЦК України) [18, ст. 745]. Примірників договору варто створювати чотири (не менше двох екземплярів згідно ст. 59 Закону України «Про нотаріат»): по одному для кожної зі сторін, один для органу, що реєструє, і один для нотаріальної контори [14].

Для обгрунтування необхідності нотаріального посвідчення цього договору існують такі аргументи: відносини мають тривалий характер, договір є алеаторним (ризиковим), особливо для одержувача ренти, його укладають особи, які, як правило, потребують особливого правового захисту [4, с. 318].

Відповідно до основних правил вчинення нотаріальних дій, нотаріус встановлює дієздатність і (або) правоздатність осіб, що звернулись за укладенням договору довічного утримання. А в разі вчинення правочину представником перевіряє його повноваження.

Оскільки договори довічного утримання (догляду) посвідчуються нотаріусами 3 дотриманням загальних правил посвідчення договорів відчуження та підлягають реєстрації, нотаріус перевіряє документи, що підтверджують право власності на майно, що відчужується [14, ст. 55].

Крім цього, відповідно до глави 5 Закону України «Про нотаріат», в обов'язки нотаріуса при посвідченні договору входить:

- роз'яснення сторонам змісту і значення поданого ними проекту договору;

- перевірка відповідності змісту проекту договору намірам сторін;

- встановлення несуперечності проекту договору вимогам закону.

Так само нотаріус перевіряє:

- наявність обтяжень, заборони відчуження або наявність арешту майна, що $\epsilon$ предметом договору;

- документи про оцінку цього майна;

- документи, передбачені Законом України «Про державну реєстрацію речових прав на нерухоме майно та їх обтяжень» [12].

Важливо зазначити, що в обов'язки нотаріуса входить надання фізичним i юридичним особам сприяння у здійсненні їхніх прав та захисті законних інтересів, попередження про наслідки вчинюваних нотаріальних дій для того, щоб юридична необізнаність не могла бути використана їм на шкоду (ст. 5 Закону України «Про нотаріат») [14, ст. 5].

Крім усього перерахованого вище, нотаріус з'ясовує наступне коло питань:

- сімейний стан особи, яка укладає договір, в результаті чого має бути надано або письмову заяву особи, що вона не перебуває в шлюбі, або наявність нотаріально засвідченої згоди другого з подружжя на здійснення договору (для спільного майна подружжя);

- згода законних представників і (або) органу опіки та піклування на укладання договору, коли це вимагається відповідно до закону. При з'ясуванні цього моменту, i 3 метою виключення суперечливості договору закону, нотаріусу пред'являють 


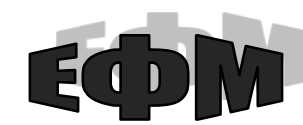

http://efm.vsau.org/

відповідні документи (згідно Державного реєстру прав на нерухоме майно) про те, хто зареєстрований у відчужуваному житловому приміщенні. Тоді стане зрозумілим, чи порушить такий договір суб'єктні права і чи потрібна згода органу опіки та піклування.

Головними елементами договору довічного утримання є:

- перехід майна до власності набувача за умови розпорядження цим майном набувачем лише після смерті відчужувача, при цьому нотаріально накладається заборона у відчуженні такого майна в установленому порядку (відповідний напис на всіх примірниках договору) (ст. 73 ЗУ «Про нотаріат»);

- формується зобов'язання із довічного утримання щодо чітко визначеної фізичної особи (власника або третьої особи (утриманця) відповідно до ч. 4 ст. 746 ЦК України);

- набувач (новий власник) не має права розпоряджатися (права подарувати, продати, закласти, обтяжувати боргами і т.д.) таке майно за життя відчужувача, це вказується в самому договорі. Нотаріус накладає заборону на таке розпорядження, про що вносить відповідний запис до реєстру обтяжень нерухомого майна;

- договір має тривалий характер і вимагає від набувача систематичного та постійного виконання своїх обов'язків на противагу договору дарування (втрата права власності на житло без умов і гарантій) [6, с. 64].

Нотаріус має з'ясувати, що у підсумку бажає отримати відчужувач майна, та чи погоджується з бажанням відчужувача той, кому має перейти майно у власність, тобто набувач [19, с. 37].

Відповідно до ст. 746 ЦК України сторонами в договорі довічного утримання (догляду) є відчужувач та набувач. Відчужувачем може бути будь-яка фізична особа незалежно від віку та стану здоров'я (ч. 1 ст.746 ЦК України). Набувачем може бути повнолітня дієздатна фізична особа або юридична особа (ч. 2 ст.746 ЦК України). Якщо набувачем є кілька фізичних осіб, вони стають співвласниками майна, переданого їм за цим договором на праві спільної сумісної власності, їх обов'язок перед відчужувачем $\epsilon$ солідарним, тобто вони в однаковій мірі відповідають перед відчужувачем за виконання своїх обов'язків, і в разі невиконання обов'язків одним з набувачів, всі обов'язки за договором має виконувати інший (інші). Згідно з загальними вимогами щодо чинності правочину (ст. 203 ЦК України), особа, яка його вчиняє, має необхідний обсяг цивільної дієздатності. Набувач (часто) платить відчужувачу велику суму в момент укладення договору (приблизно 30-40\% від вартості квартири) і виплачує обумовлену в договорі суму на утримання щомісяця [9, с. 59].

Набувач стає власником майна відразу після підписання договору, але не може розпоряджатися квартирою до вступу договору в силу, тобто до смерті відчужувача. Відчужувач, зі свого боку, не може розпоряджатися квартирою після підписання договору, але має право проживати в ній довічно.

Нотаріальна консультація для відчужувача полягає в ознайомленні його 3 наступними правами:

- обгрунтувати та вказати умови забезпечення його житлом, зокрема у будинку (квартирі), що ним передано набувачу за договором;

- означити всі види матеріального забезпечення, догляду (опікування), що надаватиме йому чи третій особі набувач;

- вимагати виконання умов договору з надання утримання (догляду), зокрема безпосередньо набувачем; 
- за потреби має право порушувати питання про заміну майна, переданого за договором довічного утримання (догляду), на іншу річ;

- розірвати договір у разі неналежного виконання набувачем своїх зобов'язань у судовому порядку [10].

Нотаріальна консультація для набувача полягає в ознайомленні його 3 наступними правами:

- здійснювати право користування й володіння таким майном за виконання відповідних умов, якщо договором не передбачено інше;

- якщо договір укладено на утримання кількох осіб (співвласників майна, що було передане набувачеві), у разі смерті одного 3 них набувач має право на зменшення обсягу зобов язань щодо утримання відчужувача (-ів) (ч. 1 ст.747 ЦК України);

- за взаємною згодою з відчужувачем набувач має право вирішити питання про заміну переданого йому за договором майна на іншу річ. Заміна речі повинна відбуватися на підставі внесення змін до договору довічного утримання (догляду) 3 дотриманням вимог до форми цього договору;

- набувач має право визначити у заповіті спадкоємців щодо майна, яке передане йому за договором довічного утримання (до них також перейдуть його зобов'язання за цим договором);

- набувач має право на розірвання договору [10].

При цьому варто вказати на відсутність права за життя відчужувача передавати майно у власність іншій особі на підставі будь-якого правочину (окрім заповіту), укладати щодо нього договір іпотеки (застави). На таке майно за життя відчужувача не може бути звернене стягнення. Втрата, знищення або пошкодження майна, переданого за договором набувачу, не $\epsilon$ підставою для припинення чи зменшення обсягу його обов'язків перед відчужувачем [10].

Серед обов'язків набувача варто виокремити:

- забезпечувати відчужувача чи утриманця (третю особу) згідно з умовами договору матеріальним утриманням та/або доглядом (опікою) довічно;

- забезпечувати відчужувача чи утриманця (третю особу) житлом;

- у разі смерті відчужувача(чів) поховати його (їх). Якщо договір укладено відчужувачем на користь третьої особи, цей обов'язок може бути покладений на набувача щодо третьої особи (утриманця) згідно домовленості сторін.

У ст. 752 ЦК України вказано, що за неможливості подальшого виконання фізичною особою обов'язків набувача за договором довічного утримання з підстав, що мають істотне значення, обов'язки набувача можуть бути передані за згодою відчужувача члену сім’ї набувача або іншій особі за їхньою згодою. При вирішенні питання про заміну набувача пріоритет мають члени його родини. Інша особа може стати набувачем лише за згодою відчужувача і первісного набувача [10].

Відмова відчужувача у наданні згоди на передання обов'язків набувача за договором довічного утримання (догляду) іншій особі може бути оскаржена в суді. У цьому разі суд бере до уваги тривалість виконання договору та інші обставини, які мають істотне значення [10].

Варто обгрунтувати й правові наслідки та підстави припинення договору довічного утримання (догляду). Так, згідно зі ст. 755 ЦК України, договір довічного утримання (догляду) може бути розірваний за рішенням суду: 
- «на вимогу відчужувача чи третьої особи (на користь якої він був укладений) у разі неналежного виконання або невиконання набувачем своїх обов'язків незалежно від його вини;

- за вимогою набувача;

- за смерті відчужувача» [18, ст. 755].

Припинення договору довічного утримання (догляду) у разі смерті відчужувача (чи утриманця (третьої особи) посвідчується нотаріально.

У договорі обов'язково має бути зазначено: право жити в цій квартирі до смерті, вартість квартири, сума першого платежу, розмір щомісячної виплати і терміни їх надання, умови індексації щомісячної суми платежу в зв'язку з інфляцією. Матеріальне забезпечення, яке щомісячно може надаватися відчужувачу, обов'язково підлягає грошовій оцінці [7, с. 393].

Основними перевагами договору довічного утримання є:

- можливість розірвати договір у разі, якщо друга сторона не виконує або неналежно виконує свої обов'язки;

- розірвання договору передбачає повернення майна у власність відчужувача. Витрати набувача (витрачені на утримання) не компенсуються;

- при погіршенні матеріального становища набувача, договір розривається і майно повертається відчужувачу у власність;

- у разі смерті набувача, обов'язки за договором переходять до його спадкоємців. Спадкоємці мають право відмовитися від дотримання договору. При цьому майно повертається відчужувачу у власність;

- випадки втрати, знищення або пошкодження нерухомого майна, переданого за договором набувачу, все одно накладають на набувача обов'язки утримання відчужувача за договором;

- набувач не має права до смерті відчужувача продавати, дарувати, міняти будинок або квартиру, передану за договором довічного утримання, складати стосовно неї договір застави, передавати у власність іншій особі на підставі іншого правочину;

- варто звернути увагу на покращення стану нерухомого майна, що може здійснювати набувач. Істотною умовою договору довічного утриманням $\epsilon$ повна турбота про майно. Можуть виникнути випадки, що набувач покращує стан майна тільки для власного задоволення і житла. Ця обставина є однією з умов розірвання договору;

- набувач зобов'язаний у разі смерті відчужувача поховати його, навіть якщо це не було передбачено договором довічного утримання;

- смерть набувача чи припинення юридичної особи-набувача не є підставою для однозначного припинення договору довічного утримання (догляду), оскільки обов'язки за договором переходять до спадкоємців (правонаступників) набувача. I тільки у випадку відсутності спадкоємців або їх відмови від прийняття спадщини та у випадку повної ліквідації (без правонаступників) юридичної особи договір довічного утримання (догляду) також припиняється [6, с. 64].

Проблемними моментами дії такого договору є:

-на основі передачі нерухомого майна у власність набувача, відчужувач більше не має можливості розпоряджатися цим майном без згоди іншої сторони згідно з договором (заповідати таке майно чи навіть прописувати будь-кого в ньому); 


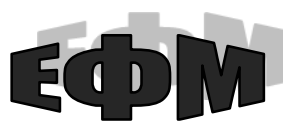

http://efm.vsau.org/

-варто підписувати договір з довіреними особами - перевіреними і порядними людьми (зниження ризиковості договору);

-укладаючи договір, відчужувачу варто чітко формулювати власні бажання в майбутньому змісті договору (гарантія виконання вимог в письмовій формі);

-набувач може бути зобов'язаний забезпечити відчужувача або третю особу житлом у будинку (квартирі), який йому переданий за договором довічного утримання (догляду). У цьому разі в договорі має бути конкретно означена та частина помешкання, в якій відчужувач має право проживати (ст. 750 ЦК України);

-розірвання договору здійснюється в судовому порядку [6, с. 62].

Разом $з$ тим, для набувача при укладенні такого договору необхідно звернути увагу на особистість того, хто має бути відчужувачем. При необачності така сторона ризикує наштовхнутися на деякі неприємності. По-перше, оскільки відчужувач, як правило, хвора і літня людина, то при укладанні договору з такою особою інша сторона ризикує визнання такого правочину недійсним на підставі ст. 225-227 ЦК України (недійсність договору, укладеного особою, не здатною розуміти значення своїх дій або під впливом істотної помилки) [18]. У суді, як показує практика, довести це дуже легко, тому, щоб уникнути несприятливих наслідків, рекомендується вимагати у відчужувача відповідні довідки з психоневрологічного та наркологічного диспансеру, які підтверджують його дієздатність, а при необхідності - виписку 3 амбулаторної картки. 3 цього ж фактора випливає те, що набувачам слід побоюватися «несподіваних» спадкоємців і родичів потенційного відчужувача, оскільки вони мають право на розірвання такого договору, грунтуючись на тих же ст. 225-227 ЦК України [5].

Прикладом вищезазначеного можуть бути обставини однієї справи: позивач звернувся до суду з вимогою визнати договір довічного утримання, укладений між старенькою матір'ю позивача і відповідачем, недійсним на підставі ст. 203 та ст. 225 ЦК України. Позивач вказав, що мати позивача на момент укладення договору була психічно хвора і не могла усвідомлювати своїх дій та керувати ними. Відповідач же повірив матері позивача щодо стану їі здоров'я, вважаючи, що вона психічно здорова i, не замислюючись, уклав договір 3 нею. Таким чином, суд, отримавши необхідні докази у вигляді висновку судово-психіатричної експертизи, довідки центральної лікарні, визнав таку особу нездоровою в психічному плані, а отже, нездатною укладати договори такого типу. Як підсумок - задоволення позову та визнання недійсним договору. Більш того, платник матеріальної допомоги в такому випадку втрачає передане йому нерухоме майно, залишившись тільки 3 неповерненими витратами без права на грошову компенсацію [5].

За умови подачі позову за життя відчужувача про розірвання договору про довічне утримання, факт його смерті до вирішення справи судом допускає правонаступництво у спірних правовідносинах відповідно до ст. 37 ЦПК України, залучають до участі у справі правонаступника відчужувача, до якого внаслідок розірвання договору довічного утримання згідно зі ст. 1218 ЦК України переходять і всі права та обов'язки відчужувача [18].

Дискусійним $є$ положення закону про конкретне визначення частини помешкання для проживання відчужувача (ст. 750 ЦК України). Чому сторони мають визначати саме якусь частину, якщо вони домовляються, що у користуванні відчужувача залишається все помешкання без обмежень? Або як визначити цю 


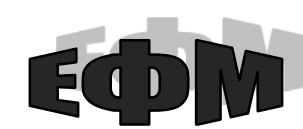

http://efm.vsau.org/

частину в однокімнатній квартирі чи в кімнаті гуртожитку? Вважаємо, що сторони в цьому випадку можуть скористатися принципом диспозитивності, що випливає 3 норм статті 6 ЦК України 18].

Закон захищає відчужувача від небезпеки втрати майна набувачем до припинення договору довічного утримання (догляду) за його зобов'язаннями, тобто кредитори набувача не мають права звернути стягнення на майно набувача, набуте ним за договором довічного утримання (простіше кажучи, забрати за борги), протягом життя відчужувача.

3 правом власності на майно до набувача переходить і ризик випадкового знищення речі. Втрата (знищення) або пошкодження майна не звільняє його від виконання в повному обсязі обов'язків, покладених на нього договором.

У випадку, коли набувач через певні істотні обставини не в змозі надалі надавати відчужувачу належне матеріальне забезпечення або догляд, зобов'язання у відповідності з договором можуть перейти до членів сім'ї набувача або до іншої особи, але для цього необхідна обов'язкова згода як відчужувача, так і особи, яка виявить бажання взяти на себе обов'язки набувача. Відчужувач, зі свого боку, має право заперечувати передання обов'язків набувача за договором довічного утримання іншій особі. Проте набувач має право звернутися до суду для вирішення цього питання. Про перехід до осіб, які будуть виконувати обов’язки набувача, права власності на майно, передане за договором, мова не йде.

Сторони в договорі довічного утримання (догляду) 3 тих чи інших причин, які виникли у процесі дії договору, можуть домовитися (шляхом укладення додаткового договору або договору про внесення змін) про заміну майна, яке було передане набувачеві, на інше. У цьому разі обсяг обов'язків набувача в залежності від вартості нового майна може бути за домовленістю сторін змінений або залишений незмінним.

Договір довічного утримання (догляду) може бути розірваний на підставі рішення суду на вимогу відчужувача або третьої особи, на користь якої він укладений, у разі невиконання або неналежного виконання набувачем своїх обов'язків. У цьому разі витрати, понесені набувачем на утримання та (або) догляд відчужувача, не підлягають поверненню.

У разі неможливості виконання набувачем своїх обов'язків за його позовом договір довічного утримання (догляду) також може бути розірваний у судовому порядку.

У випадках припинення договору довічного утримання (догляду), не пов'язаних зі смертю відчужувача, право власності на майно, що перейшло до набувача за договором, повертається відчужувачу [7, с. 321].

У разі розірвання договору у зв'язку 3 неможливістю його подальшого виконання набувачем з підстав, що мають істотне значення, суд може залишити за набувачем право власності на частину майна 3 урахуванням тривалості часу, протягом якого він належно виконував свої обов'язки за договором.

Оподаткування доходу, отриманого в результаті укладення договору довічного утримання (догляду), якщо предметом договору $\epsilon$ нерухоме майно, регулюється пунктом 172.8 статті 172 Податкового кодексу України [11]. За цією нормою перехід права власності до набувача, який відбувається в день посвідчення цього договору, прирівнюється до продажу. Тобто для цілей оподаткування відчужувач $є$ продавцем, а набувач - покупцем. Таким чином, оподатковується дохід, отриманий відчужувачем як продавцем від відчуження (продажу в розумінні статті 
172 ПКУ) об'єкта нерухомого майна. Звичайно, договірної ціни цього об'єкта, виходячи з якої визначається оподатковуваний дохід, у договорі довічного утримання бути не може, але закон вказує, що такий дохід не може бути нижчим оціночної вартості об’єкта, розрахованої відповідним суб'єктом оціночної діяльності. Отже, податок за договором довічного утримання (догляду) визначається 3 оціночної вартості переданого за договором нерухомого майна та сплачується до бюджету відчужувачем.

Такий дохід може взагалі не оподатковуватися, якщо предметом договору $є$ житлова нерухомість або земельна ділянка за умови перебування такого майна у власності відчужувача понад три роки або успадкування майна, незалежно від строку перебування у власності, а також за умови відчуження такого об'єкту вперше протягом звітного податкового року (з першого січня до тридцять першого грудня); під відчуженням слід розуміти будь-який перехід права власності (продаж, міна тощо), крім передачі майна в дарунок. Аналогічно оподатковується дохід, отриманий від передачі за договором довічного утримання (догляду) об'єкту рухомого майна, але в цьому випадку не оподатковується дохід від відчуження протягом звітного (податкового) року одного з об' єктів рухомого майна у вигляді легкового автомобіля та/або мотоцикла та/або мопеда.

Для набувача рекомендується підкріплювати всі платіжні операції відповідними документами: квитанціями, чеками, виписками з банку. Таким шляхом набувач зможе довести свою сумлінність у виконанні договору. Більш того, за логікою закону, сукупність витрат набувача - це всі витрати, необхідні для утримання відчужувача. Тому в договорі довічного утримання слід вказати всі конкретні зобов'язання між сторонами. Також, якщо сторони зійдуться на тому, що виконання договору може бути замінено періодичними грошовими платежами, то така умова має бути включена в договір. Вважається, що платежі повинні мати саме періодичний характер, тобто набувач не може одноразово виплатити всю суму за змістом договору.

Однією з проблем є визначення обсягу матеріального забезпечення, що щомісячно виплачується відчужувачу на його утримання. При вирішенні цієї проблеми суд повинен керуватися принципами добросовісності та розумності, відповідно до п. 2 ст. 749 ЦК України.

За договором довічного утримання варто визначити комплексно можливі види матеріального забезпечення та усі види опікування (догляду), якими відчужувача забезпечує набувач. Матеріальне забезпечення повинне надаватися відчужувачу щомісяця й підлягає грошовій оцінці та включає індексацію. Як приклад, можна навести обов'язок набувача забезпечувати відчужувача щоденним необхідним одягом, харчуванням, оплатою медобслуговування та ліків, проводити ремонт житла відчужувача, оплачувати спожиті відчужувачем комунальні послуги, проводити прання білизни й одягу і прибирання житла тощо.

Виходячи з вищесказаного, можна зробити висновок, що види і обсяг щомісячного матеріального забезпечення договору довічного утримання складаються залежно від ситуації і потреб одержувача (відчужувача).

Найпоширенішою проблемою в договорі довічного утримання є розірвання цього договору. Розірвати договір можна, якщо набувач не виконає зобов'язання щодо відчужувача. Як показує судова практика, у більшості випадків позов про 
розірвання договорів довічного утримання задовольняється. Але позови набувачів не задовольняються судами, якщо вони спрямовані на зміну терміну матеріального забезпечення, оскільки загалом законодавчо вказано про щомісячну оплату.

Багато громадян звертаються з позовом про припинення договорів внаслідок нерозуміння характеру договору (плутанина договорів купівлі-продажу 3 договором довічного утримання) або обману (омани) 3 іншого боку 3 приводу характеру договору, а також нерозуміння самого змісту договору і наслідків його укладення [5].

Абстрактність обов'язків набувача також впливає на наслідки укладеного договору. У ст. 749 ЦК України зазначено такий обов'язок набувача - матеріальне забезпечення, а також усі види догляду (опікування), якими набувач має забезпечувати відчужувача. Законодавець не закріпив чіткий перелік обов'язків, оскільки такі особливості полягають у самостійному визначенні сторонами договору умов, необхідних для кожного конкретного відчужувача. Проблема в тому, що на практиці дуже часто не всі умови обговорюються в письмовій формі, що тягне за собою суперечки в суді. Але безпосередньо в суді відчужувачі вказують на те, що обговорювали певну кількість послуг з набувачем, які він не виконав. Наведемо приклад із судової практики районного суду (справа №299/1887/18), в якому розглядалася цивільна справа між сторонами про визнання договору недійсним. ОСОБА_2 запропонувала укласти договір довічного утримання. Позивач погодився та підписав договір, однак, як було з'ясовано пізніше, було укладено договір дарування, а не договір довічного утримання. Відповідач забрала всі документи та 3 того часу ніякої допомоги позивачу не надавала. Позивач вказав, що при укладенні спірного договору його волевиявлення було спрямовано виключно на укладення договору довічного утримання, а не дарування. Позивач просить суд визнати договір дарування житлового будинку недійсним. Відповідно до ч.1 ст. 229 ЦК України, якщо особа, яка вчинила правочин, помилилася щодо обставин, які мають істотне значення, такий правочин може бути визнаний судом недійсним [5].

Відповідно до правового висновку Верховного Суду України, справа №669цс 14 від 18 червня 2014 року, відсутність особи під час укладання договору дарування волевиявлення на безоплатну передачу майна у власність обдарованого й передача його за умови вчинення на користь дарувальника будь-якої дії майнового або немайнового характеру, усупереч вимогам ст. 717 ЦК України, є підставою для визнання договору дарування недійсним на підставі ч. 3 ст. 203 ЦК України та ст. 229 ЦК України [3].

Відповідно до ч. 3 ст. 203 ЦК України волевиявлення учасника правочину має бути вільним і відповідати його внутрішній волі.

Ця ситуація $є$ прикладом введення в оману однієї із сторін, що тягне за собою недійсність договору: відповідно до п. 19 Постанови Пленуму Верховного Суду України № 9 від 06.11.2009 року «Про судову практику розгляду справ про визнання правочинів недійсними» [2], правочин, вчинений через помилку, шляхом обману, насильства, зловмисної домовленості представника однієї сторони 3 другою стороною або внаслідок впливу тяжких обставин, $\epsilon$ оспорюваним. Суд позовні вимоги задовольнив та, керуючись ст.ст.10, 12, 13, 43, 49, 259, 263-265, 268 ЦПК України, визнав недійсним Договір дарування житлового будинку [5].

У ЦК України не врегульовано випадок, коли набувач може навмисне позбавити життя відчужувача, щоб швидше заволодіти обіцяним правом власності на майно і розірвати договір. Судова практика не згадує про такі випадки. Це діяння 


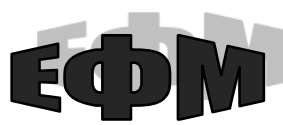

http://efm.vsau.org/

тягне за собою кримінальну відповідальність і недійсність договору. На нашу думку, поки немає законодавчого регулювання з цього питання, варто виходити із загальних засад цивільного законодавства і керуватися вимогами законності, добросовісності, розумності та справедливості. У такому випадку також можливе право вимоги повернення майна спадкоємцями в порядку правонаступництва, враховуючи неможливість заявити вимогу самим одержувачем у зв'язку зі смертю 3 вини набувача, що не залежить від волі відчужувача.

Висновки. Отже, договір довічного утримання i його регулювання в українському законодавстві є недосконалим, що може створити проблеми при його укладенні та виконанні, а також при вирішенні спірних питань. Відповідно до розглянутого договірного правочину щодо довічного утримання набувач отримує право власності на майно відчужувача або в момент нотаріального посвідчення такого договору, або за умови, що предметом договору є нерухомість, - в день проведення державної реєстрації права власності в Держреєстрі речових прав на нерухоме майно (виконання таких дій невідкладно після посвідчення договору довічного утримання (догляду). У результаті, набувачем ще при житті відчужувача отримується право власності майна відчуженого згідно договору довічного утримання (догляду). Але разом з тим, таке право є досить обмеженим, оскільки згідно закону, набувач не має права до смерті відчужувача подарувати, продати, обміняти чи іншим чином відчужити майно, що передане за договором довічного утримання (догляду), укладати щодо нього договір застави (іпотеки). Такий аспект цього правочину стосується і відчужувача - зокрема, він перестає бути власником майна в день нотаріального посвідчення договору. Згідно Закону України «Про нотаріат» й Порядку вчинення нотаріальних дій нотаріусами України, нотаріус, що посвідчує договір довічного утримання, накладає заборону відчуження цього майна, яка знімається тільки у зв'язку з припиненням цього договору. А припиненим договір довічного утримання (догляду) може бути лише з причини його розірвання або за згодою сторін, або в судовому порядку, або через смерть відчужувача.

Розглянувши основні проблеми та наслідки, пов'язані з посвідченням договору довічного утримання, можна зробити висновок, що цей інститут цивільного права потребує більш детальної законодавчої регламентації. Потрібно усунути деякі прогалини в законодавстві, а саме: докладно розкрити умови договору, чітко закріпити в цивільному законодавстві, права і обов'язки сторін, що посприяє захисту прав сторін договору та стабілізації відносин рентного типу.

Роль нотаріуса у розумінні сторонами цих договорів, їх правової природи $\epsilon$ визначальною і досить нелегкою з огляду на юридичну неграмотність більшості громадян та відсутність у нашій країні доступної та кваліфікованої правової допомоги. Роз'яснення та посвідчення договору довічного утримання потребує раціонального та кваліфікованого підходу, що дозволить надалі запобігти проблемам і негативним наслідкам його виконання (неналежного виконання).

\section{Список використаних джерел}

1. Актуальні питання прикладної цивілістики: сімейне, трудове, земельне та житлове право. Науково-практичний посібник; За заг. ред. д.ю.н. професора М.М. Ясинка. К.: ЦУЛ, 2015. 450 с.

2. Висновки Верховного Суду України, викладені в постановах, ухвалених за результатами розгляду заяв про перегляд судового рішення з підстави, передбаченої п. 1 ч. 1 ст. 355 Цивільного процесуального кодексу України, за II півріччя 2013 р. URL: https://zakon.rada.gov.ua/laws/show/n0001700-14 (дата звернення 14.02.2019). 
3. Висновок Верховного Суду України, справа № 6-69цс 14 від 18 червня 2014 року (визнання договорів дарування недійсними) URL: https://oda.court.gov.ua /sud1590/pravovipoziciivsu/6-69cs14 (дата звернення: 10.02.2019).

4. Долинська М. С. Особливості нотаріального посвідчення договору довічного утримання (догляду). Актуальні проблеми держави і права. 2012. Вип. 64. С. 318-324.

5. Сдиний державний реєстр судових рішень URL: http://reyestr.court.gov.ua (дата звернення 13.02.2019).

6. Івашова I. П. Особливості правового регулювання договору довічного утримання (догляду). Науковий вісник Міжнародного гуманітарного університету. Серія : Юриспруденція. 2017. Вип. 26. С. 62-64.

7. Козир О.В. Проблемні питання договору довічного утримання URL: http://conference.nau.edu.ua/index.php/SUO/Confs_14/paper/viewFile/2181/1415 (дата звернення 14.02.2019).

8. Конституція України від 28 червня 1996 року. Відомості Верховної Ради України. 1996. № 30. Ст. 141.

9. Лаптош М. В., Куртакова А. О. Договір довічного утримання: питання теорії. Трипільська циивілізація. 2012. № 8. С. 58-62.

10. Особливості посвідчення договору довічного утримання (догляду):

Роз'яснення Міністерства юстиції України від 01.04.2011 URL: https://zakon.rada.gov.ua/laws/show/n0023323-11 (дата звернення 14.02.2019).

11. Податковий кодекс України від 02.12.2010 № 2755-VI (із змінами і доп. № 2628-VIII від 23.11.2018, BBP, 2018, № 49, ст.399) URL: http://zakon5.rada.gov.ua /laws/show/2755-17.

12. Про державну реєстрацію речових прав на нерухоме майно та їх обтяжень: Закон України від 01.07.2004 № 1952-IV (в редакції від 04.02.2019) URL: https://zakon.rada.gov.ua/laws/show/1952-15 (дата звернення: 10.02.2019).

13. Про затвердження Порядку вчинення нотаріальних дій нотаріусами України: Наказ Міністерства юстиції України від 22.02.2012 № 296/5 URL: https://zakon.rada.gov.ua/laws/show/z0282-12 (дата звернення: 10.02.2019).

14. Про нотаріат: Закон України від 02.09.1993 № 3425-XII (в редакції від 04.02.2019) URL: https://zakon.rada.gov.ua/laws/show/3425-12

15. Розгон О.В. Теоретичні та практичні аспекти виконання договору довічного утримання. Юридичний науковий електронний журнал. 2016. №2. С.39-42.

16. Сімейний кодекс України від 10.01.2002 р. № 2947-III (в редакції від 28.08.2018) URL:https://zakon.rada.gov.ua/laws/show/2947-14 (дата звернення: 20.01.2019).

17. Ткаченко М. В. Зміст договору довічного утримання (догляду). Розвиток сучасного права в умовах глобальної нестабільності: матеріали міжнародної науково-практичної конферениії (Одеса, 8-9 вересня 2017 р.). Одеса, 2017. С. 47-52.

18. Цивільний кодекс України від 16.01.2003 р. № 435-IV (із змінами і доп. № 2628-VIII від 23.11.2018) URL: http://zakon2.rada.gov.ua/laws/show/435-15 (дата звернення: 20.01.2019).

19. Цопіна Н. Договір довічного утримання (догляду): питання правової характеристики. Юридична Україна. 2017. № 4. С. 34-40. 


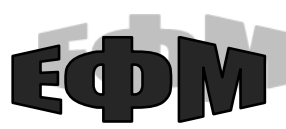

http://efm.vsau.org/

\section{References}

1. Yasynko M.M. (2015). Aktual'ni pytannya prykladnoyi tsyvilistyky: simeyne, trudove, zemel'ne ta zhytlove pravo [Actual questions of applied civil law: family, labor, land and housing]. K.: TSUL, 450 p. [in Ukrainian].

2. Vysnovky Verkhovnoho Sudu Ukrayiny, vykladeni v postanovakh, ukhvalenykh za rezul'tatamy rozhlyadu zayav pro perehlyad sudovoho rishennya $z$ pidstavy, peredbachenoyi $p .1$ ch. 1 st. 355 Tsyvil'noho protsesual'noho kodeksu Ukrayiny [Conclusions of the Supreme Court of Ukraine, set in the resolutions adopted on the basis of the results of consideration of applications for review of a court decision on the grounds provided for in paragraph 1, part 1, Article. 355 of the Civil Procedural Code of Ukraine]. Retrieved from: https://zakon.rada.gov.ua/laws/show/n0001700-14 [in Ukrainian].

3. Vysnovok Verkhovnoho Sudu Ukrayiny [Conclusion of the Supreme Court of Ukraine], sprava № 6-69tss 14 (2014, June 18) (vyznannya dohovoriv daruvannya nediysnymy) Retrieved from: https:/oda.court.gov.ua/sud1590/pravovipoziciivsu/6$69 \operatorname{cs} 14$ (accessed 10.02.2019) [in Ukrainian].

4. Dolyns'ka M.S. Osoblyvosti notarial'noho posvidchennya dohovoru dovichnoho utrymannya (dohlyadu) [Features of the notarial certificate of the contract of life maintenance (care)]. Aktual'ni problemy derzhavy i prava - Actual issues of state and law, 2012, 64, 318-324 [in Ukrainian].

5. Yedynyy derzhavnyy reyestr sudovykh rishen' [Unified state register of court decisions of Ukraine]. Retrieved from: http://reyestr.court.gov.ua [in Ukrainian].

6. Ivashova I. P. Osoblyvosti pravovoho rehulyuvannya dohovoru dovichnoho utrymannya (dohlyadu) [Features of legal regulation of the contract of life maintenance (care)]. Naukovyi visnyk Mizhnarodnoho humanitarnoho universytetu. Seriia : Yurysprudentsiia - Scientific Herald of the International Humanitarian University. Series: Jurisprudence, 2017, 26, 62-64 [in Ukrainian].

7. Kozyr O.V. Problemni pytannya dohovoru dovichnoho utrymannya [Problem issues of the lifetime maintenance agreement]. Retrieved from: http://conference.nau.edu.ua/index.php/SUO/Confs_14/paper/viewFile/2181/1415 [in Ukrainian].

8. Konstytutsiya Ukrayiny [The Constitution of Ukraine] (1996, June 28) [in Ukrainian].

9. Laptosh M.V., Kurtakova A.O. Dohovir dovichnoho utrymannya: pytannya teoriyi [Treaty of life maintenance: theoretical issues]. Trypilska tsyvilizatsiia - Trypillya civilization, 2012, 8, 58-62 [in Ukrainian].

10. Osoblyvosti posvidchennya dohovoru dovichnoho utrymannya (dohlyadu) [Features of the certificate of the contract of life maintenance (care)]: Roz"yasnennya Ministerstva yustytsiyi Ukrayiny (2011, April 1). Retrieved from: https://zakon.rada.gov.ua/laws/show/n0023323-11 [in Ukrainian].

11. Podatkovyy kodeks Ukrayiny [The Tax Code of Ukraine] (2010, December 2) № 2755-VI. Retrieved from: http://zakon5.rada.gov.ua/laws/show/2755-17 [in Ukrainian].

12. Pro derzhavnu reyestratsiyu rechovykh prav na nerukhome mayno ta yikh obtyazhen' [About the state registration of real rights to real estate and their encumbrances]. Law of Ukraine. Retrieved from: https://zakon.rada.gov.ua /laws/show/1952-15 [in Ukrainian]. 
13. Pro zatverdzhennya Poryadku vchynennya notarial'nykh diy notariusamy Ukrayiny: Nakaz Ministerstva yustytsiyi Ukrayiny [On approval of the procedure for the commission of notarial acts by notaries of Ukraine] (2010, February 22) № 296/5. Retrieved from: https://zakon.rada.gov.ua/laws/show/z0282-12 [in Ukrainian].

14. Pro notariat [About the notary: Law of Ukraine] (2019, February 4). Retrieved from: https://zakon.rada.gov.ua/laws/show/3425-12 [in Ukrainian].

15. Rozhon O.V. Teoretychni ta praktychni aspekty vykonannya dohovoru dovichnoho utrymannya [Theoretical and practical aspects of the implementation of the contract of life maintenance]. Legal scientific electronic journal, 2016, 2, 39-42 [in Ukrainian].

16. Simeynyy kodeks Ukrayiny [Family Code of Ukraine] (2018, August 28). Retrieved from: https://zakon.rada.gov.ua/laws/show/2947-14 [in Ukrainian].

17. Tkachenko M. V. (2017). Zmist dohovoru dovichnoho utrymannya (dohlyadu) [The content of the contract of life maintenance (care)]. Rozvytok suchasnoho prava $\mathrm{v}$ umovakh hlobalnoi nestabilnosti: materialy mizhnarodnoi naukovo-praktychnoi konferentsii - Development of modern law in the conditions of global instability: materials of the international scientific and practical conference. Odesa, 2017, 47-52 [in Ukrainian].

18. Tsyvil'nyy kodeks Ukrayiny [Civil code of Ukraine] (2018, November 23) № 435-IV. Retrieved from: http://zakon2.rada.gov.ua/laws/show/435-15 [in Ukrainian].

19. Tsopina N. Dohovir dovichnoho utrymannya (dohlyadu): pytannya pravovoyi kharakterystyky [The contract of life maintenance (care): the question of legal characteristics]. Yurydychna Ukraina - Legal Ukraine, 2017, 4. 34-40 [in Ukrainian].

\section{Відомості про автора}

ГАВІНСЬКА Олена Андріївна - кандидат юридичних наук, асистент кафедри права, Вінницький національний аграрний університет (21000, м. Вінниця, бульвар Свободи, 8/25, e-mail: Alyonagaleta@gmail.com.

HAVINSKA Elena - Candidate of Law Sciences, Lecturer of the Department of Law, Vinnytsia National Agrarian University (21000, Vinnytsia, 8/25 Svobody Boulevard, e-mail: Alyonagaleta@gmail.com.

ГАВИНСКАЯ Елена Андреевна - кандидат юридических наук, ассистент кафедры права, Винницкий национальный аграрный университет $(21000$, г. Винница, бульвар Свободы, 8/25, e-mail: Alyonagaleta@gmail.com.

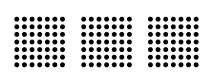

